\title{
USE OF SYNTHETIC SKIN SUBSTITUTE (BIOBRANE) FOR
}

\author{
PLANTAR FOOT BURN
}

\author{
Johandi F. ${ }^{1}$, Feng JJ ${ }^{1}$, Ruth FML2, Chong SJ ${ }^{1}$, Tan BK${ }^{1}$, Tan KC ${ }^{1}$ \\ 1. Department of Plastic, Reconstructive and Aesthetic Surgery, Singapore General Hospital, Singapore \\ 2. Division of Plastic, Reconstructive and Aesthetic Surgery, Department of Surgery, Cipto Mangunkusumo National General \\ Hospital, Indonesia
}

Background : In Singapore, we experience a unique annual surge of burn cases involving sole of foot during the Hindu fire walking festival. Traditionally, superficial partial-thickness burns of the soles were managed expectantly with regular dressings. We conducted a study to evaluate the effectiveness of an alternative approach of using synthetic skin substitute (Biobrane $\left.{ }^{\circledR}\right)$.

Method : A case series of foot burns admitted October 2016 to the Singapore General Hospital Burns Centre. Burn cases with superficial partial-thickness burn of bilateral sole of foot were included in the study. Exclusion criteria included deep dermal burns and burns that required excision and closure with skin grafting. The patient demographics, time to presentation, medical co-morbidities were analyzed. Outcomes such as length of hospital stay, incidence of infection, need for further surgery, return to pre-injury ambulation status and occupation and cost were studied.

Result : A total of 6 partial thickness burns of sole of foot in 3 patients with bilateral foot burns which were treated with Biobrane ${ }^{\circledR}$ were included in the study. Patients were able to return pre-injury functional status- return to work and pre-morbid ambulation status. Neither incidence of wound infections nor any needs for repeat surgery were recorded. However, this group required an increased length of stay and incurred high treatment cost.

Conclusion: Biobrane ${ }^{\circledR}$ is a viable adjunct in the management of sole of foot burns. The authors believe there is potential for an improved rate of recovery with Biobrane ${ }^{\circledR}$. However, the higher cost and length of stay are among its drawbacks. In view of the limitations of our study-case series and small sample size, a prospective and double arm assessment will be required to present definite evidence for synthetic skin substitute in these cases

Keywords: Foot, Sole, Burn, Biobrane

Latar Belakang: Di Singapura, kami mengalami lonjakan tahunan yang unik dalam kasus luka bakar yang melibatkan telapak kaki dalam Hindu fire walking festival. Secara tradisional, luka bakar superficial partialthickness pada telapak kaki dirawat dengan balutan dengan penggantian berkala. Kami mengevaluasi keefektifan dari pendekatan alternatif menggunakan penggunaan pengganti kulit sintetis (Biobrane $\left.{ }^{\circledR}\right)$.

Metodologi: Serial kasus luka bakar pada kaki di bulan Oktober 2016 di Singapore General Hospital Burns Centre. Kasus luka bakar dengan superficial partial-thickness pada kedua telapak kaki dimasukkan kedalam penelitian. Kriteria ekslusi adalah luka bakar kulit yang dalam dan luka bakar yang memerlukan eksisi dan penutupan dengan cangkok kulit. Demografi pasien, waktu kejadian, ko-morbiditas medis akan dianalisis. Lama perawatan di rumah sakit, kejadian infeksi, apakah diperlukan operasi lebih lanjut, kembali ke status ambulasi pra-cedera, pekerjaan dan biaya adalah hasil yang akan dipelajari.

Hasil: Sebanyak 6 luka bakar partial thickness pada telapak kaki dari 3 pasien dengan luka bakar kaki bilateral yang di terapi dengan Biobrane ${ }^{\circledR}$ dimasukkan dalam penelitian ini. Pasien dapat kembali ke status fungsional sebelum cedera, kembali bekerja dan status ambulasi pre-morbid. Tidak ada insiden infeksi pada luka maupun operasi ulang. Namun, didapatkan bertambahnya lama rawat dan biaya pengobatan yang lebih tinggi.

Kesimpulan: Biobrane ${ }^{\circledR}$ merupakan terapi tambahan yang layak dipertimbangkan dalam pengelolaan luka bakar pada telapak kaki. Penulis yakin bahwa dengan Biobrane ${ }^{\circledR}$ terdapat potensi tingkat pemulihan yang lebih baik. Namun, kekurangannya adalah bertambahnya biaya dan lama perawatan. Mengingat keterbatasan rangkaian studi kasus dan ukuran sampel yang sedikit, dalam kasus ini penilaian prospektif dan double arm diperlukan untuk menunjukkan bukti pasti pengganti kulit sintetis.

Kata Kunci : Foot, Sole, Burn, Biobrane 


\section{INTRODUCTION}

The annual fire walking ceremony is a religious festival celebrated by the Hindu community where male devotees walk across a burning charcoal pit.1,2 During the festival, our institution will experience an increased number of foot burn cases.

Biobrane ${ }^{\circledR}$ is a bi-layered synthetic skin substitute which has been shown to be effective in treating superficial, partial-thickness skin burns. Its advantages includes reduced need of dressing changing, pain control, reduced length of hospital stay and improved healing time. ${ }^{3-6}$ Traditionally, superficial partial-thickness burns of the sole are managed expectantly with regular dressings. We evaluate the effectiveness of an alternative approach of using Biobrane ${ }^{\circledR}$.

\section{METHOD}

A case series of foot burns admitted October 2016 to the Singapore General Hospital Burns Centre. Burn cases with superficial partial-thickness burn of bilateral sole of foot were included in the study. Exclusion criteria included deep dermal burns and burns that required excision and closure with skin grafting. The patient demographics, time to presentation, medical co-morbidities were analyzed. Outcomes such as length of hospital stay, incidence of infection, need for further surgery, return to preinjury ambulation status and occupation and cost were studied.

\section{RESULT CASE 1}

A previously healthy 30 -year-old Indian man presented with superficial partial thickness burn injury due to fire-walking barefooted. He was admitted on the day of the injury. He underwent wound debridement and Biobrane ${ }^{\circledR}$ application one day after admission. Intra-operative findings included 1\% TBSA on the left sole and 1\% TBSA on the right sole. First wound inspection on Post Operation Day (POD) 2 showed that Biobrane ${ }^{\circledR}$ was stable and took well, no signs of infection. He was discharged on POD 2. Second wound inspection was done on POD 4 in clinic with Biobrane ${ }^{\circledR}$ stable, the wound healing well. At the third wound inspection on POD 10, as can be seen in Image 1, Biobrane ${ }^{\circledR}$ was ready to be trimmed as the wound was clean and epithelializing. There was no sign of infection and no need for repeat surgery. He was able to perform light duties 10 days after the surgery and returned to employment as a business manager one month after injury.

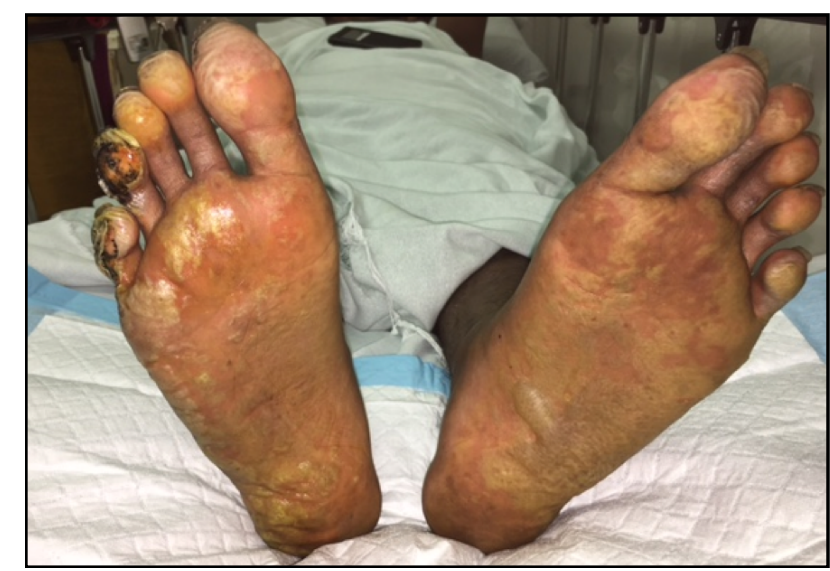

Figure 1. Superficial partial thickness burn post Biobrane ${ }^{\circledR}$ application

\section{CASE 2}

A previously healthy 32-year-old Indian man presented with superficial partial thickness burns due to fire-walking barefooted. He was admitted on the day of the injury. He underwent burn wound debridement and Biobrane ${ }^{\circledR}$ application on the day of admission. Intra-Operatively, it was noted that he sustained 1\% TBSA on the left sole and $1 \%$ TBSA on the right sole. Wound inspection done on POD 2 showed that wound was clean but slightly moist. He was continued on light-iodine gauze dressing and discharged on POD 8 . Subsequently, wound inspection on POD 10 (Image 2) in clinic showed that wound was clean and epithelialized with no sign of infection. A repeat surgery was not indicated. He was able to return to light duties at work from POD10 and returned to premorbid work as a safety officer one month after surgery.

Disclosure: The authors have no financial interest to disclose. 

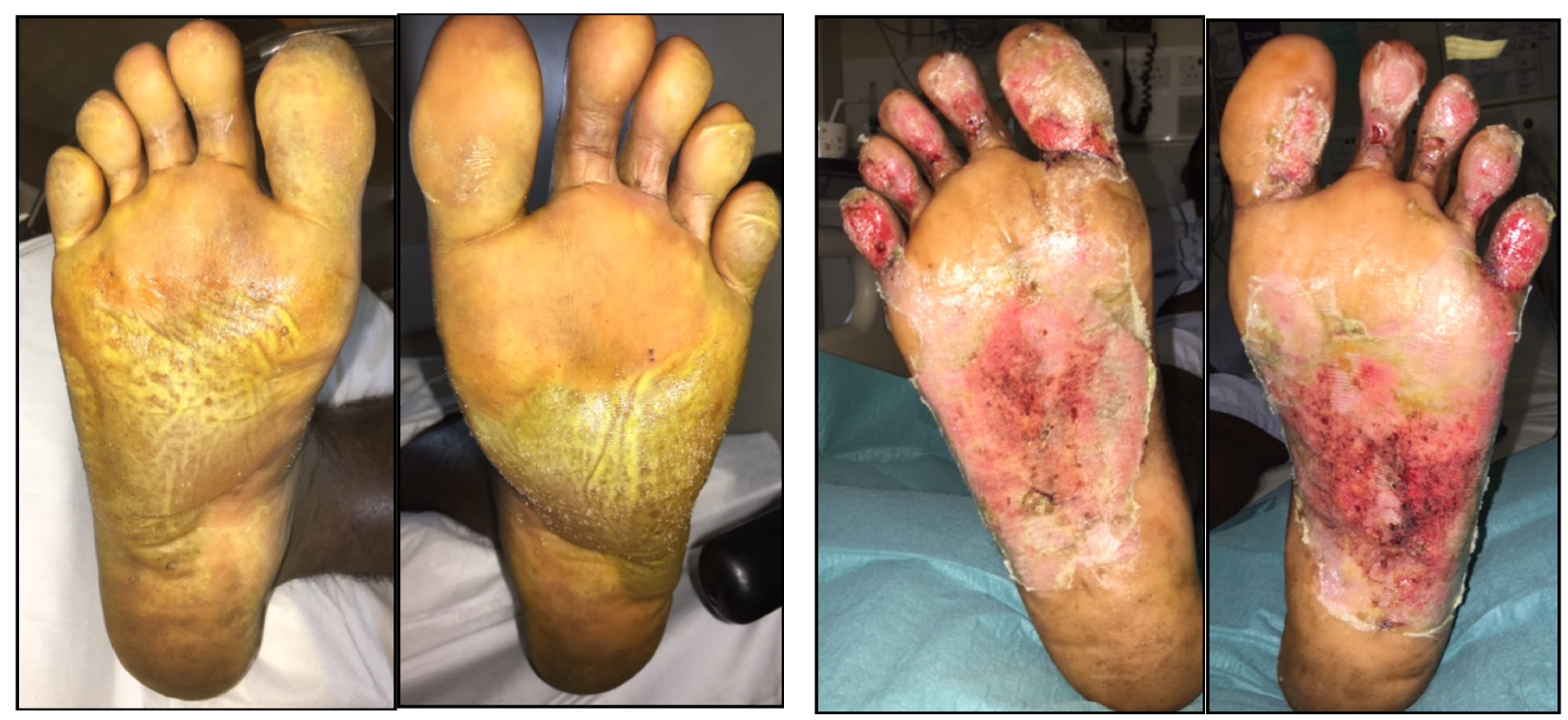

Figure 2. Superficial partial thickness burn prior to Biobrane ${ }^{\circledR}$ application (left), superficial partial thickness burn post Biobrane ${ }^{\circledR}$ application (right)

\section{CASE 2}

A 32-year-old Indian man presented with partial thickness mid-dermal burn injury due to firewalking barefooted. He was admitted three days after the injury. He has asthma and works as an office worker. He underwent burn wound debridement and Biobrane ${ }^{\circledR}$ application 5 days after the injury. Intraoperatively, noted patient sustained 3\% TBSA of bilateral feet burns over soles and pulps of toes. The right foot was partial thickness to mid-dermal burns and the left foot was mid dermal burns. At the first wound inspection on POD 2, Biobrane ${ }^{\circledR}$ was stable and wound was clean. Subsequent wound inspection on POD 6 showed that Biobrane ${ }^{\circledR}$ was taking well. He was discharged on POD 6. At the outpatient wound inspection on POD 12, as can be seen in Image 3, wound was epithelialized, except for a small raw area over the left fifth toe. There was no sign of infection and no need repeat surgery indicated. He returned to light duty on from POD 12 and returned to full employment one month post operation.
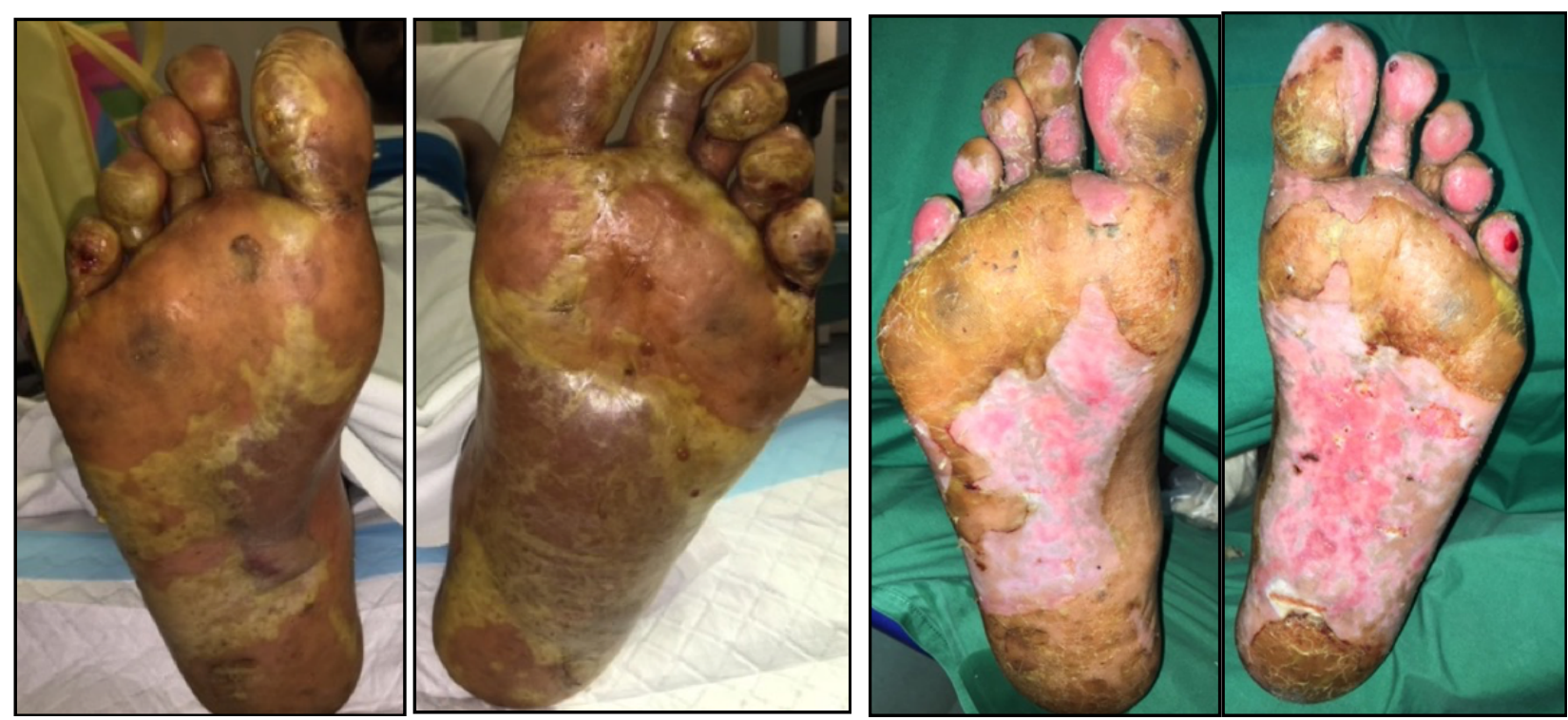

Figure 3. Partial thickness mid-dermal burn prior to Biobrane ${ }^{\circledR}$ application (left), partial thickness middermal burn post Biobrane ${ }^{\circledR}$ application (right). 


\section{DISCUSSION}

The use of Biobrane ${ }^{\circledR}$ for superficial partial thickness burn has been proven to be successful. 4,5 The cost incurred for these three patients range from 2378 - 2951 US dollar. The cost is higher compare to traditional dressing, in example paraffin gauze. The superiority of Biobrane ${ }^{\circledR}$ compared to paraffin gauze is that we did not need to change it. In another research by Austin et al, Biobrane ${ }^{\circledR}$ and cadaveric allograft showed no statistically significant difference, although cadaveric allograft cost more than Biobrane ${ }^{\circledR 6}$

Longer length of stay may caused by the use of Biobrane ${ }^{\circledR}$. Krezdorn et al showed that Biobrane ${ }^{\circledR}$ did not prove to have beneficial effects on length of stay. In elder patients, Biobrane ${ }^{\circledR}$ may prolonged the length of stay. ${ }^{3}$ This was opposite to the research of Fan et al, which showed Biobrane ${ }^{\circledR}$, compared to silver foam, has significantly shorter length of stay in paediatric patients with partial thickness burns. ${ }^{7}$

\section{CONCLUSION}

Biobrane ${ }^{\circledR}$ is a viable adjunct in the management of sole of foot burns. The authors believe there is potential for an improved rate of recovery with Biobrane ${ }^{\circledR}$. However, the higher cost and length of stay are among its drawbacks. In view of the limitations of our study-case series and small sample size, a prospective and double arm assessment will be required to present definite evidence for synthetic skin substitute in these cases.

\section{Corresponding author :}

Ruth F. M. Lumbun

ruthlumbuun@yahoo.com

\section{REFERENCES}

1. Sayampanathan AA. Fire walking in Singapore-A study of the distribution of burns. Burns 37 (2011) 503-507

2. Hubik DJ, Wasiak J, Paul E, Cleland H. Biobrane: A retrospective analysis of outcomes at a specialist adult burns centre. Burns 37 (2011) 594-600.

3. Krezdorn N, Könneker S, Paprottka FJ, Tapking C, Mett TR, Brölsch GF, et al. Biobrane versus topical agents in the treatment of adult scald burns. Burns 43 (2017) 195-199.

4. Cheah AKW, Chong SJ, Tan BK. Early Experience with Biobrane ${ }^{\mathrm{TM}}$ in Singapore in the Management of Partial Thickness Burns. Proceedings of Singapore Healthcare 23 (2014) 3.

5. Whitaker IS, Worthington S, Jivan S, Phipps A. The use of BiobraneW by burn units in the United Kingdom: A national study. Burns 33 (2007) 10151020.

6. Austin RE, Merchant N, Shahrokhi S, Jeschke MG. A comparison of BiobraneTM and cadaveric allograft for temporizing the acute burn wound: Cost and procedural time. Burns 41 (2015) 749753.

7. Fan C, Chong HP, Por YC, Lim GJS. Biobrane dressing for paediatric burns in Singapore: a retrospective review. Singapore Med J 2018, 1-16. 